\title{
DFT Calculations and In silico Study of Chlorogenic, Ellagic and Quisqualic acids as Potential Inhibitors of SARS-CoV-2 Main Protease Mpro
}

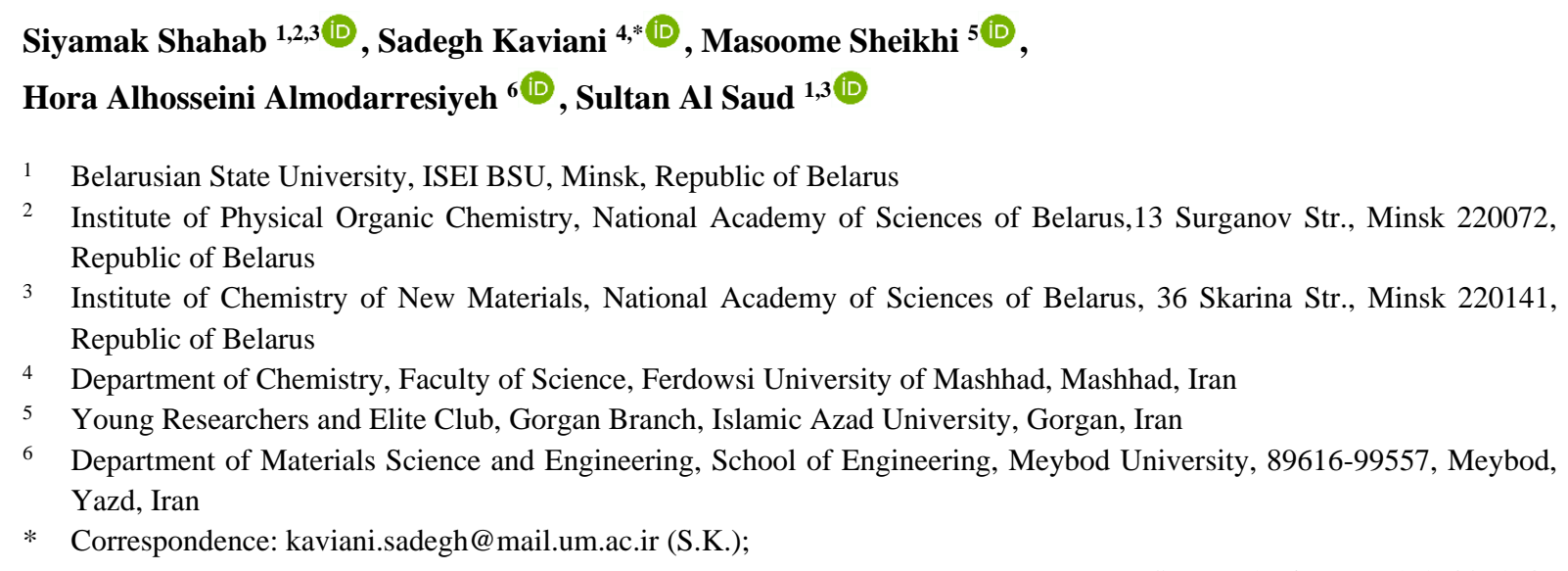

Received: 7.03.2021; Revised: 5.04.2021; Accepted: 9.04.2021; Published: 19.04.2021

\begin{abstract}
In the present work, at first, density functional theory calculations were performed to investigate the molecular structure of the Chlorogenic, Ellagic, and Quisqualic acids by CAMB3LYP/MidiX level of theory. A detail of quantum molecular descriptors of the title compounds such as ionization potential (IP) and Electron Affinities (EA), Hardness ( $)$ ), Softness (S), Electronegativity $(\mu)$, Electrophilic Index $(\omega)$, Electron Donating Power $(\omega-)$, Electron Accepting Power $(\omega+)$ and Energy Gap (Eg) have been calculated. Pharmacokinetic properties of the title compounds and their bioactivity were investigated. In the following, a molecular docking study was carried out to screen for an effective available compound that may work as a strong inhibitor for the SARS-CoV-2 main protease Mpro. The binding energy between SARS-CoV-2 main protease Mpro and title organic acids showed a good binding affinity. Therefore, the Chlorogenic, Ellagic, and Quisqualic acids can be used for potential application against the SARS-CoV-2 main protease Mpro.
\end{abstract}

Keywords: SARS-CoV-2 main protease $\mathrm{M}^{\text {pro; }}$ DFT; molecular docking; chlorogenic; Ellagic and Quisqualic acids; pharmacokinetic properties.

(c) 2021 by the authors. This article is an open-access article distributed under the terms and conditions of the Creative
Commons Attribution (CC BY) license (https://creativecommons.org/licenses/by/4.0/).

\section{Introduction}

The appearance of a severe acute respiratory syndrome (SARS-CoV-2) created a pandemic in the Wuhan city and more than 212 countries, resulting in over 27 million infections and about 900.000 deaths worldwide [1-4]. SARS-CoV-2 falls into the category of RNA viruses, which causes disorders in hepatic, pulmonary, central nervous, and gastrointestinal systems [5,6]. SARS-CoV-2 can encode cysteine proteases, including the chymotrypsin-like cysteine $\left(3 \mathrm{CL}^{\text {pro }}\right)$ or main protease $\left(\mathrm{M}^{\text {pro }}\right)$ and the papain-like cysteine protease $\left(\mathrm{PL}^{\text {pro }}\right)$, which are responsible for catalyzing the proteolysis of polyproteins translated from the genome of the virus into nonstructural proteins required for packaging the nascent virion and replication of virus [7-10]. Therefore, inhibition of the activity of these proteases would prevent the virus 
replication. $\mathrm{M}^{\text {pro }}$ hydrolyzes the GIn-Ser peptide bond in the Leu-GIn-Ser-Ala-Gly sequence, which is different from the peptide sequence identified by other human cysteine proteases [11]. Therefore, $\mathrm{M}^{\text {pro }}$ is considered a promising site for designing anti-SARS-CoV-2 drugs.

Chlorogenic acid (CGA) is an important biologically active phenolic compound, being the main component of coffee and tea produced by the plant's special species [12-14]. It is recently receiving high attention due to its many promising useful effects related to its antiinflammatory and antioxidant properties, such as regulation of glucose and lipid metabolism in cardiovascular [15], diabetes [16], cancer [17], and fatty liver [18] diseases. Before absorption of CGA in the gastrointestinal system, it is hydrolyzed to caffeic acid and quinic acid through the functioning of certain microbial esterases in both small and large intestine, while after absorption, it is metabolized to glucuronide and sulfate as circulating species in plasma [19,20]. Based on Hoelzl et al.'s reports, the high levels of Chlorogenic acid in coffee decrease 8isoprostaglandin F2 $\alpha$ and 3-nitrotyrosine about 15.3 and 16.1\%, respectively, inducing a protective effect against the damage generated by free radicals [21]. Sapio et al. reported that Chlorogenic acid has an inhibitory effect on the proliferation of osteosarcoma (OS) cells, which provides promising novel strategies in OS treatment [22].

Ellagic acid (EA) is a natural polyphenol compound with great antioxidant and anticancer activities [23-25]. Its antioxidant efficacy is exerted by stimulation of the activity of antioxidant enzyme systems, whereas the anti-cancer characteristic of Ellagic acid is related to its capability to inhibit growth and tumor diffusion as well as increasing the sensitivity of tumor cells to chemotherapy and radiotherapy [26-29]. Guptaa et al. showed the inhibitory potential of Ellagic acid towards SphK1 as a therapeutic method to control sphingosine kinase 1 (SphK1)-dependent pathologies, such as cancer and diabetes [30]. Yousuf et al. demonstrated that Ellagic acid could be a potential inhibitor of Cyclin-Dependent Kinase 6 (CDK6) in breast cancer treatment [31]. Wang et al. suggested that Ellagic acid inhibits breast cancer metastasis via regulation of ACTN4 in vitro and in vivo [32].

Quisqualic acid (QA) is an amino acid isolated from the seeds of Quisqualis indica, which acts as an agonist of glutamate, kainate, and metabotropic receptors in the central nervous systems (CNS) of mammalians [33,34]. Since quisqualate has an uncertain effect on synaptic transmission, Quisqualic acid can induce an increased sensitivity of neurons to depolarization by analogs of phenyl glycine, homoibotenic (HIBO) acid, and 2-amino-4phosphonobutyric acid (AP4) [35]. Bitzer et al. concluded Quisqualic acid reduces ZENK expression, which causes myopia [36]. According to Rochford et al., Quisqualic acid affects the rabbit eye's standing potential through its functioning on the retinal pigment epithelium [37].

In silico and computational approaches are low-cost methods for predicting pharmacokinetics' pharmacokinetics properties before experimental procedures, which give us basic data in bioinformatics research [38-42]. In this study, computational/In silico methods are utilized to screen the potential inhibitory of Chlorogenic, Ellagic, and Quisqualic acids for SARS-CoV-2 main protease $\mathrm{M}^{\text {pro }}$. ADMET characteristics are evaluated to represent selected inhibitors' compatibility for human administration, whereas molecular docking and DFT investigations are utilized to analyze their reactivity and binding with SARS-CoV-2 main protease $\mathrm{M}^{\mathrm{pro}}$. 


\section{Materials and Methods}

\subsection{ADME analysis.}

Lipinski's Rule of Five [43] was used to investigate organic acids that were selected for this study. Filters like Molecular weight of the ligand ( $<500 \mathrm{Da})$, high lipophilicity $(\operatorname{LogP}<5)$, number of hydrogen bonds donors $(<5)$, number of hydrogen bond acceptors $(<10)$, and Molar refractivity (40-130) (Ghose Rule) were used to carry out the further selection of the title organic acids. Violation of more than 2 of the above-stated parameters debarred further analysis of a particular molecule. Parameter details were calculated from using Molinspiration Cheminformatics software [44].

\subsection{Bioactivity score.}

The investigated acids' bioactivity was predicted by calculating the activity score toward G protein-coupled receptors (GPCR ligand), ion channel modulator, nuclear receptor ligand, a kinase inhibitor, protease inhibitor, and enzyme inhibitor with the help of online software Molinspiration (www.molinspiration.com).

\subsection{DFT investigation.}

A Pentium IV personal computer (CPU at $4.80 \mathrm{GHz}$ ) with the Windows 10 operating system was used. The initial geometry optimization of title compounds was performed with HyperChem (Version 8.0 Hypercube, Inc., Alberta, Canada). For all the ab initio calculations, Gaussian 16 was employed [45]. The molecular properties of the compounds were calculated by CAM-B3LYP/MidiX level of theory $[46,47]$. The lowest energy structures of the species were computed by conformational analysis. Geometry optimization was performed at the CAM-B3LYP level with the same basis set. The following formulas were applied to calculate the electronic properties of the title molecules [48]:

$$
\begin{gathered}
\mathrm{IP}=- \text { Еномо, }(\mathrm{eV}) \\
\mathrm{EA}=- \text { Eluмо, }(\mathrm{eV}) \\
\eta=(\mathrm{IP}-\mathrm{EA}) / 2,(\mathrm{eV}) \\
\mathrm{S}=1 / 2 \eta,(\mathrm{eV}) \\
\mu=(\mathrm{IP}+\mathrm{EA}) / 2,(\mathrm{eV}) \\
\omega=\mu^{2} / 2 \eta,(\mathrm{eV}) \\
\omega^{+}=(\mathrm{IP}+3 \mathrm{EA})^{2} / 16(\mathrm{IP}-\mathrm{EA}),(\mathrm{eV}) \\
\omega^{-}=(3 \mathrm{IP}+\mathrm{EA})^{2} / 16(\mathrm{IP}-\mathrm{EA}),(\mathrm{eV}) \\
\mathrm{E}_{\mathrm{g}}=\text { E } \mathrm{\text {Luмо }}-\text { Еномо },(\mathrm{eV})
\end{gathered}
$$

The geometry optimization was performed in the gas phase. The optimized molecular structures, HOMO and LUMO surfaces, were visualized using Gauss View 05 program [49].

\subsection{Molecular docking.}

The molecular docking studies were performed by using the AutoDock/Vina tool [50]. It is a reliable protein-ligand docking tool that uses the Broyden-Goldfarb-Shanno algorithm, which significantly improves the binding mode prediction's average accuracy. The crystal structure of the target protein (PDB ID: 7CBT) (Figure 1) was downloaded from the Protein Data Bank (http://www.rcsb.org/pdb) in PDB format and was prepared by AutoDock tools. Visualization of the docked pose has been done using CHIMERA (www.cgl.ucsf.edu/chimera) and Molegro Molecular Viewer 2.5 (www.clcbio.com/products/molegro/\#molecular-viewer). 
Water molecules and amino acid that does not belong to the protein were removed by deleting the lines that start with "HETATM" and "CONNECT". The file structure was saved and ready for docking analysis. Manually initialized the protein molecule by adding hydrogen atoms and kolmen charges using the edit option and saved the protein molecule as write PDB. A grid box of $50 \times 50 \times 50 \AA$ centered at $(-27.325,17.891,76.447) \AA$ for the SARS-CoV-2 main protease was used in the docking experiments. Biovia Discovery Studio Visualizer v19.1.0.18287 [51] was used to view the docking results and to convert the structures into pdb format. Binding energies $(\Delta \mathrm{G}, \mathrm{kcal} / \mathrm{mol})$ of the docked ligands were obtained by $\Delta \mathrm{G}=-\mathrm{RTLnK} \mathrm{K}_{\mathrm{i}}$, where $\mathrm{R}=$ Gas constant $\left(1.987 \cdot 10^{-3} \mathrm{kcal} / \mathrm{mol}\right) ; \mathrm{T}=298.15 \mathrm{~K} ; \mathrm{K}_{\mathrm{i}}=$ Inhibition constant. PubChem repository ("PubChem") was used to obtain the structure of the title organic acids required for the analysis in pdb format (Figure 2).

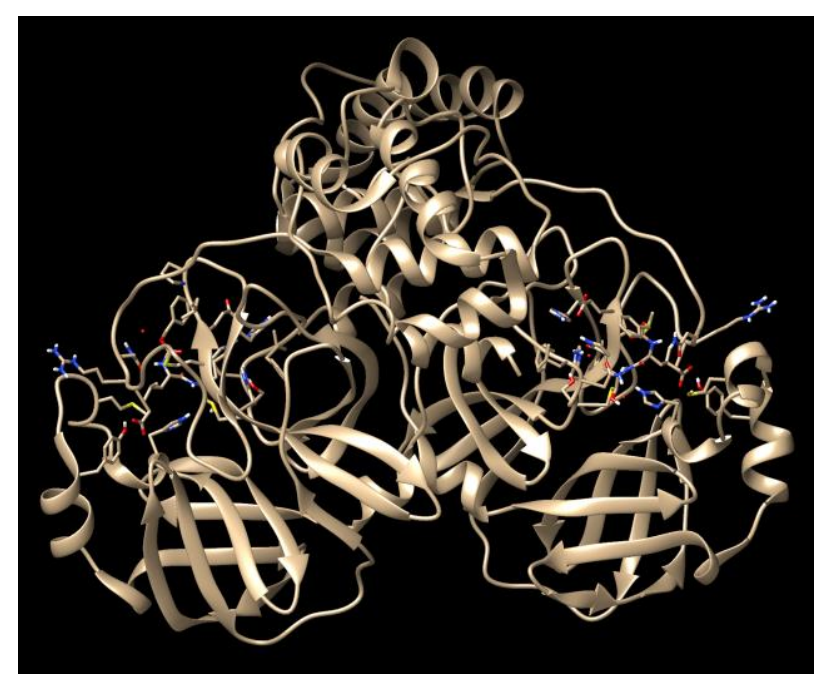

Figure 1. The crystal structure of target protein (PDB ID: 7CBT).

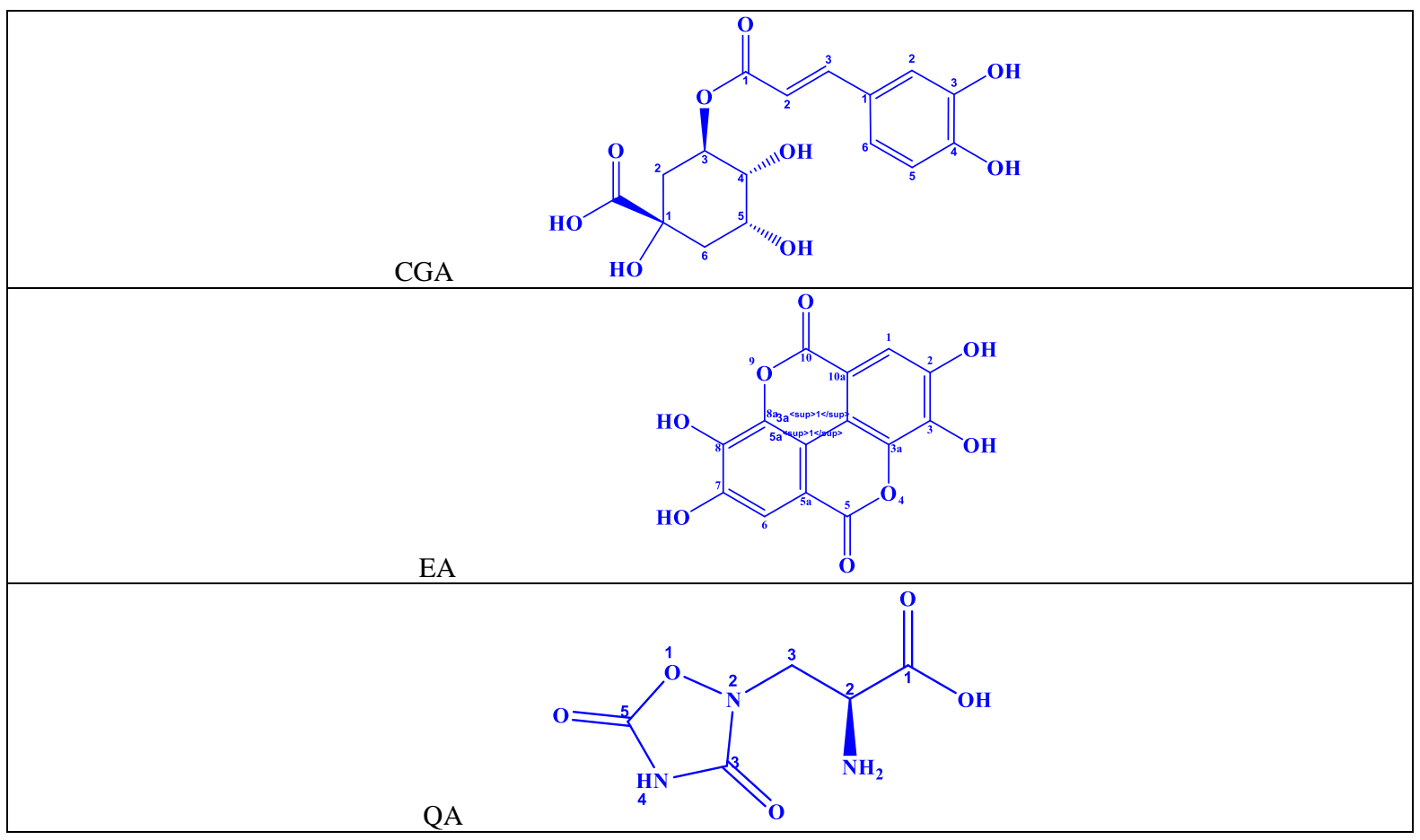

Figure 2. The chemical structures of the title organic acids. 


\section{Results and Discussion}

\subsection{Pharmacokinetic properties.}

Drug-likeness estimated using the Lipinski rule of five, which is including of four simple physicochemical parameter ranges (MWT $\leq 500, \log \mathrm{P} \leq 5, \mathrm{H}$-bond donors $\leq 5$, H-bond acceptors $\leq 10$ ) related to $90 \%$ of drugs with good oral bioavailability that have passed phase II clinical trial. miLogP values of these compounds are observed to be $<5$ (from -4.40 to 0.94 ) showed their good permeability across the cell membrane. These compounds (Ellagic acid and Quisqualic acid) were observed to have TPSA will be below $160 \AA$, molecular weight $<500$, No. of hydrogen bond donors $\leq 5$, No. of hydrogen acceptor $\leq 10$, n-violations 0 , number of rotatable flexible bonds $>5$. Solubility $(\log S)$ property of a drug in an aqueous solution affects absorption and distribution characteristics. A compound's solubility is predicted using ChemBioOffice 2018 software to identify the low solubility behavior and eliminate it from the study based on $\log S$ value [52]. The preferred value is greater than -4 . Solubility in water can be considered as the number of hydrogen donors in molecules. A higher amount of hydrogen bond donor translates a higher amount of water solubility, leading to high absorption into the blood and action. The molecular weight of all compounds was found to be less than five hundred, and thereby these compounds are predicted to be easily transported, diffused, and absorbed than compared with the large molecules. Several hydrogen bond acceptors (notably $\mathrm{O}$ and $\mathrm{N}$ atoms) and a number of hydrogen bond donors of the Ellagic and Quisqualic acids were in agreement with Lipinski's rules (less 10 and 5, respectively). The numbers of rotatable bands are important for conformational changes of the molecules. The oral bioavailability criteria, the number of rotatable bands, should be less or equal to ten. All studied acids have a number of rotatable bands between 0 and 5, consequently showing large conformational flexibility. Topological polar surface area (TPSA) is correlated with the hydrogen bonding of a drug molecule. Topological polar surface area is a very good indicator of the bioavailability of the drug molecules. TPSA of the Ellagic and Quisqualic acids were observed in the range of 131.33 to $141.33 \AA$. The results of the calculations are presented in Table 1 .

Table 1. Pharmacokinetic properties of the title compounds

\begin{tabular}{c|c|c|c|c|c|c|c|c|c} 
Compound & miLogP & TPSA & natoms & MW & nHBA & nHBD & nviolations & nrotb & LogS \\
\hline CGA & -0.45 & 164.74 & 25 & 354.31 & 9 & 6 & 1 & 5 & -2.00 \\
\hline EA & 0.94 & 141.33 & 22 & 302.19 & 8 & 4 & 0 & 0 & -2.65 \\
\hline QA & -4.40 & 131.33 & 13 & 189.13 & 8 & 4 & 0 & 3 & 1.69
\end{tabular}

*_mLogP: lipophilicity; TPSA: Total Polar Surface Area; MW: Molecular Weight; nHBA: number of hydrogen bond acceptors; nHBD: number of hydrogen bond donors; $n$ violations: number of violated drug-likeness rules; nrotb: number of rotating bonds; LogS: solubility

\subsection{Bioactivity}

These bioactivity scores for organic molecules can be interpreted as active (when the bioactivity score is $>0$ ), moderately active (when the bioactivity score lies between -5.0 and 0.0 ), and inactive (when the bioactivity score $<-5.0$ ). That means that Quisqualic acid can be considered bioactive as a GPCR ligand, Ion channel modulator, Nuclear receptor ligand, Protease inhibitor, Enzyme inhibitor, and moderately active as a Kinase inhibitor. The Ellagic acid can be considered bioactive as a Nuclear receptor ligand, Enzyme inhibitor, and moderately active as a GPCR ligand, Ion channel modulator, Kinase inhibitor, Protease inhibitor, and Enzyme inhibitor. The Chlorogenic acid can be considered bioactive as a GPCR 
ligand, Ion channel modulator, Nuclear receptor ligand, Protease inhibitor, Enzyme inhibitor, and moderately active as a Kinase inhibitor. The bioactivity score profile of all structures is given in Table 2.

Table 2. Bioactivity scores against different drug targets of the title compounds

\begin{tabular}{c|c|c|c|c|c|c} 
Compound & $\begin{array}{c}\text { GPCR } \\
\text { ligand }\end{array}$ & $\begin{array}{c}\text { Ion channel } \\
\text { modulator }\end{array}$ & $\begin{array}{c}\text { Kinase } \\
\text { inhibitor }\end{array}$ & $\begin{array}{c}\text { Nuclear receptor } \\
\text { ligand }\end{array}$ & $\begin{array}{c}\text { Protease } \\
\text { inhibitor }\end{array}$ & $\begin{array}{c}\text { Enzyme } \\
\text { inhibitor }\end{array}$ \\
\hline CGA & 0.29 & 0.14 & 0.00 & 0.74 & 0.27 & 0.62 \\
\hline EA & -0.29 & -0.27 & -0.01 & 0.11 & -0.18 & 0.17 \\
\hline QA & 0.52 & 1.26 & -0.55 & 0.22 & 0.81 & 1.18
\end{tabular}

\subsection{DFT calculations.}

The highest occupied molecular orbital (HOMO) and the lowest unoccupied molecular orbital (LUMO) are known as the frontier molecule orbitals (FMOs) (Figure 3) that participate in electronic properties, optical properties, UV/Vis spectrum, and chemical reactions [36]. We used FMO analysis and the title organic acids' electronic properties by CAM-B3LYP/MidiX level of theory. The calculated results are reported in Table 3. A detail of quantum molecular descriptors of the title compounds such as Ionization Potential (IP) and Electron Affinities (EA), Hardness $(\eta)$, Softness $(S)$, Electronegativity $(\mu)$, Electrophilic Index $(\omega)$, Electron Donating Power $\left(\omega^{-}\right)$, Electron Accepting Power $\left(\omega^{+}\right)$and Energy Gap (Eg) have been calculated. The energy of HOMO is directly related to the ionization potential (IP), while the energy of LUMO is related to the electron affinity (EA) [53]. The nucleophilicity of the studied organic acids can be expressed by the potential ionization value, which is calculated as the necessary energy for an electron's abstractions in the molecule. IP shows the easiness of the title molecules' electron-donating due to electron abstraction is the first antioxidant mechanism. Therefore, structures with low IP values can undergo oxidation more easily (Chlorogenic acid with IP $=0.2095 \mathrm{eV})$. The Electron Affinity (EA) of the Quisqualic acid is the lowest $(0.0050$ $\mathrm{eV}$ ). The global Hardness $(\eta)$ corresponds to the energy gap between LUMO and HOMO. A molecule with a small energy gap has high chemical reactivity, low kinetic stability, and a soft molecule, while a hard molecule has a large energy gap [54-56]. Quisqualic acid higher global Hardness, and it is a hard molecule. Electronegativity $(\mu)$ is a measure of the power of an atom or a group of atoms to attract electrons and the chemical softness (S). It describes the capacity of an atom or a group of atoms to receive electrons. The Electrophilic Index $(\omega)$ represents the systems' stabilization energy when it becomes saturated by electrons. The results show that Quisqualic acid has the lowest value $\omega$ and is nucleophilic in nature, whereas the Ellagic acid has the highest value $\omega$ and is strongly electrophilic. In addition, among the set of compounds, the Ellagic acid has the highest Electron Accepting Power $\left(\omega^{+}\right)$and Electron Donating Power $\left(\omega^{-}\right)$values (0.0661 and $0.2046 \mathrm{eV}$, respectively). As shown in Table 3, the value of $\mathrm{Eg}_{\mathrm{g}}$ for the Chlorogenic acid $(0.1522 \mathrm{eV})$ is the lowest. Thus, this structure can act better as an antioxidant.

Table 3. The calculated electronic properties in eV of the title organic acids by CAM-B3LYP/MidiX level of theory.

\begin{tabular}{c|c|c|c|c|c|c|c|c|c} 
Structures & $\mathbf{I P}$ & $\mathbf{E A}$ & $\boldsymbol{\eta}$ & $\mathbf{S}$ & $\boldsymbol{\mu}$ & $\boldsymbol{\omega}$ & $\boldsymbol{\omega}^{+}$ & $\boldsymbol{\omega}^{-}$ & $\mathbf{E}_{\mathbf{g}}$ \\
\hline CGA & 0.2095 & 0.0573 & 0.0761 & 0.0381 & 0.1334 & 0.1169 & 0.0597 & 0.1932 & 0.1522 \\
\hline EA & 0.2149 & 0.0622 & 0.0763 & 0.0382 & 0.1386 & 0.1258 & 0.0661 & 0.2046 & 0.1527 \\
\hline QA & 0.2463 & 0.0050 & 0.1206 & 0.0603 & 0.1256 & 0.0654 & 0.0177 & 0.1433 & 0.2413
\end{tabular}




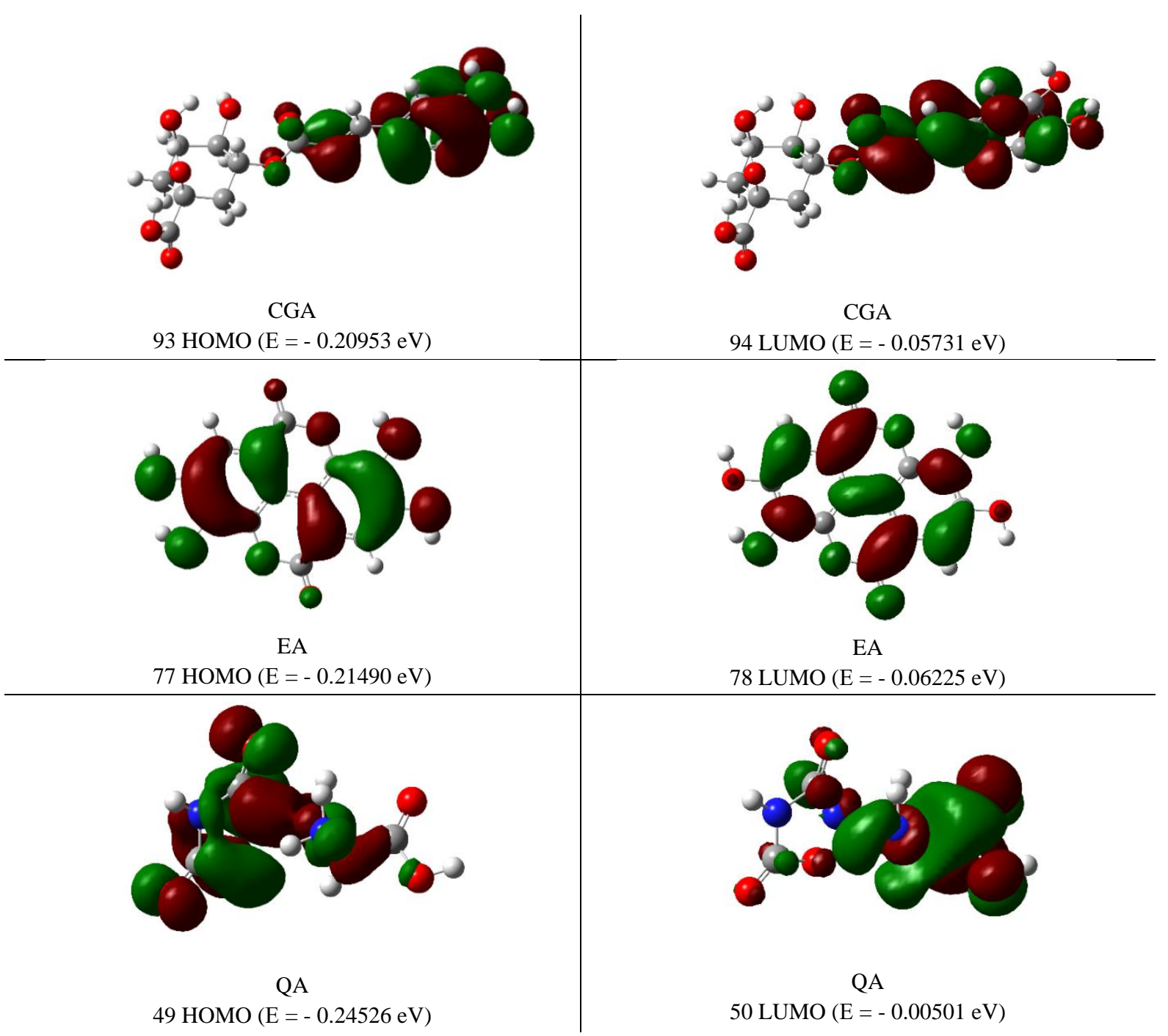

Figure 3. Calculated frontier molecule orbitals (FMOs) of the Chlorogenic, Ellagic, and Quisqualic acids by CAM-B3LYP/MidiX level of theory.

\subsection{Molecular docking analysis.}

To study potential inhibitor of SARS-CoV-2 Mpro, AutoDock/Vina (MGL tools 1.5.6), CHIMERA, Molegro Molecular Viewer 2.5, and Biovia Discovery Studio 4.5 were applied. The ligands were docked to the active site of the receptor protein molecule (Figure 4). The docking and glide scores of the Chlorogenic, Ellagic, and Quisqualic acids were presented in Table 4, which has binding energy, glide score, number of hydrogen bonds, and steric interactions formed. The maximum number of hydrogen bonds and steric interactions validates the strong binding energy.

It is seen from Table 4 that the binding energy of the Chlorogenic, Ellagic, and Quisqualic acids with SARS-CoV-2 main protease $\mathrm{M}^{\text {pro }}$ are $-12.980,-15.955,-10.476 \mathrm{kcal} / \mathrm{mol}$ with an inhibition constant $1.206,2.012 .10^{-6}$ and $0.021 \mu \mathrm{M}$, respectively. It is observed that the studied organic acids are taken for the investigations exhibit better binding energy and various interactions involving hydrogen bonds and steric interactions with the SARS-CoV-2 main protease $\mathrm{M}^{\text {pro }}$. The scoring function is a mathematical method predicting the strength of binding affinity between protein and ligand complex. 

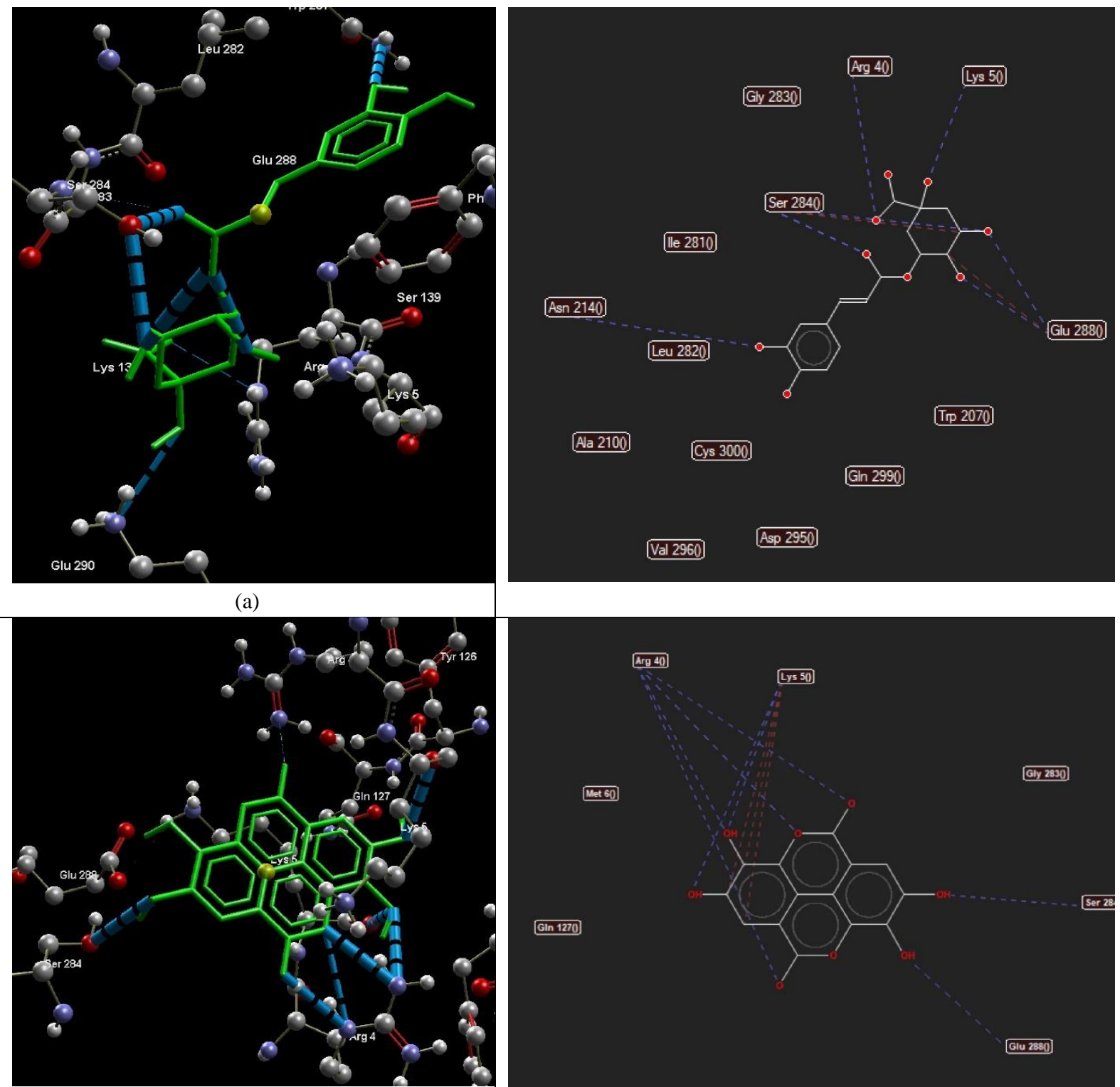

(a)

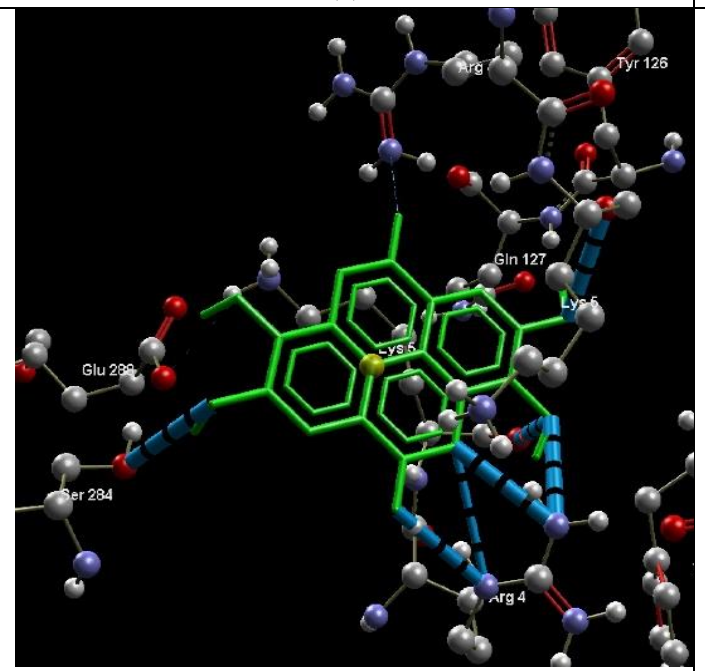

(b)

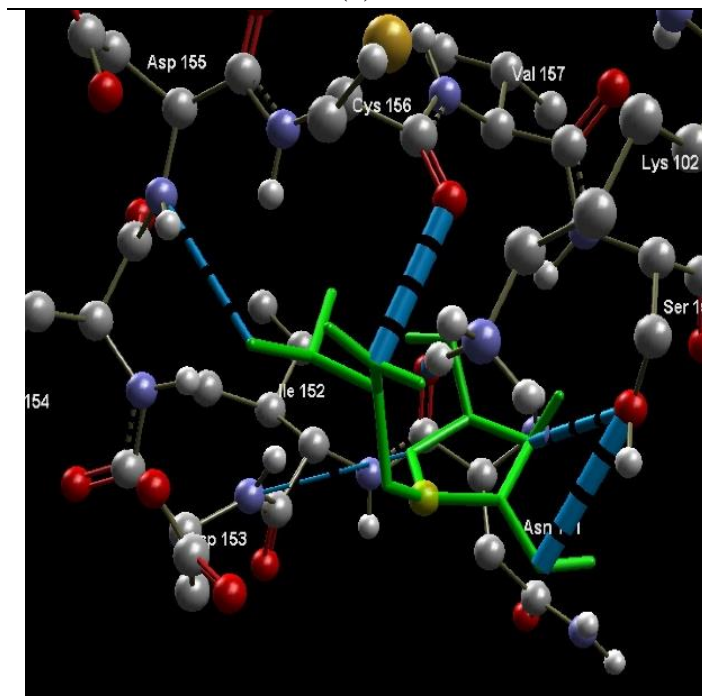

Ser 158

V(val100
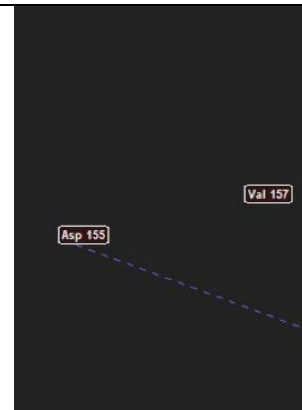

Phe 150

Val 197

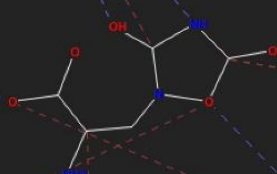

(4ss 155

[4r 159]

(c)

Figure 4. (a) Chlorogenic acid; (b) Ellagic acid; (c) Quisqualic acid binding interactions with SARS-CoV-2 main protease Mpro. 
Table 4. Molecular docking analysis of the Chlorogenic, Ellagic, and Quisqualic acids with SARS- CoV-2 main

\begin{tabular}{|c|c|c|c|c|c|c|c|}
\hline Ligands & $\begin{array}{l}\text { Binding } \\
\text { Energy, } \\
\text { kcal/mol }\end{array}$ & $\begin{array}{c}\text { Inhibition } \\
\text { constant } \\
\left(\mathbf{k}_{\mathbf{i}}\right), \mu \mathrm{M}\end{array}$ & $\begin{array}{c}\text { Glide } \\
\text { Score, } \\
\text { kcal/mol }\end{array}$ & $\begin{array}{l}\text { Number } \\
\text { of } \mathrm{H}- \\
\text { bonds }\end{array}$ & $\begin{array}{c}\text { Number of } \\
\text { Steric } \\
\text { Interactions }\end{array}$ & $\begin{array}{c}\text { 7CBT Receptor } \\
\text { amino acids forming } \\
\text { H-bonds with ligands }\end{array}$ & $\begin{array}{c}\text { Steric } \\
\text { Interactions }\end{array}$ \\
\hline CGA & -12.980 & 1.206 & -94.824 & 6 & 2 & $\begin{array}{c}\text { Arg 4, Lys 5, } \\
\text { Ser 284, Asn 214, } \\
\text { Glu } 288\end{array}$ & $\begin{array}{c}\text { Ser 284, Glu } \\
288\end{array}$ \\
\hline EA & -15.955 & $\begin{array}{c}2.012 \\
.10^{-6}\end{array}$ & -76.344 & 8 & 3 & $\begin{array}{c}\text { Arg 4, Lys 5, } \\
\text { Ser 284, Glu } 288\end{array}$ & Lys 5 \\
\hline QA & -10.476 & 0.021 & -65.758 & 6 & 6 & $\begin{array}{l}\text { Ser 158, Asn 151, Asp } \\
153 \text {, Cys 156, Asp } 155\end{array}$ & $\begin{array}{c}\text { Ser 158, } \\
\text { Asn 151, } \\
\text { Asp 153, } \\
\text { Cys 156, } \\
\text { Lys } 102, \text { Lie } \\
152\end{array}$ \\
\hline
\end{tabular}

\section{Conclusions}

Density functional theory calculations were performed to investigate the Chlorogenic, Ellagic and Quisqualic acids' molecular structure by CAM-B3LYP/MidiX level of theory. The ionization Potential (IP) of the Chlorogenic acid is $0.2095 \mathrm{eV}$, and this structure can act better as an antioxidant. The global Hardness $(\eta)$ of the Quisqualic acid is $0.1206 \mathrm{eV}$, and it is the hardest molecule. The Ellagic acid has the highest Electron Accepting Power $\left(\omega^{+}\right)$and Electron Donating Power $(\omega-)$ values $(0.0661$ and $0.2046 \mathrm{eV}$, respectively). miLogP values of these compounds are observed to be $<5$ (from -4.40 to 0.94 ) showed their good permeability across the cell membrane. The Ellagic and Quisqualic acids were observed to have TPSA will be below $160 \AA$, molecular weight $<500$, number of hydrogen bond donors $\leq 5$, number of hydrogen acceptor $\leq 10$, n-violations 0 , number of rotatable flexible bonds $>5$. The Quisqualic acid can be considered bioactive as a GPCR ligand, Ion channel modulator, Nuclear receptor ligand, Protease inhibitor, Enzyme inhibitor, and moderately active as a Kinase inhibitor. The Ellagic acid can be considered bioactive as a Nuclear receptor ligand, Enzyme inhibitor, and moderately active as a GPCR ligand, Ion channel modulator, Kinase inhibitor, Protease inhibitor, and Enzyme inhibitor. The Chlorogenic acid can be considered bioactive as a GPCR ligand, Ion channel modulator, Nuclear receptor ligand, Protease inhibitor, Enzyme inhibitor, and moderately active as a Kinase inhibitor.

It was found that the investigated ligands show good affinity towards of the SARSCoV-2 main protease $\mathrm{M}^{\text {pro }}$ compared to other known antiviral drugs: Colistin, Valrubicin, Icatibant, Bepotastine, Epirubicin, Epoprostenol, Vapreotide, Aprepitant in which the binding energy for SARS-CoV-2 main protease $\mathrm{M}^{\text {pro }}$ and them is $-11.206,-10.934,-9.607,-10.273$, 9.091, 10.582, -9.892 and $-11.376 \mathrm{kcal} / \mathrm{mol}$. The binding energies for SARS-CoV-2 main protease $\mathrm{M}^{\text {pro }}$ and the Chlorogenic, Ellagic, and Quisqualic acids are -12.980, -15.955 and $10.476 \mathrm{kcal} / \mathrm{mol}$ with an inhibition constant $1.206,2.012 .10-6$ and $0.021 \mu \mathrm{M}$, respectively in which show the good binding affinity between them and SARS-CoV-2 main protease $\mathrm{M}^{\text {pro }}$.

\section{Funding}

This research received no external funding. 


\section{Acknowledgments}

The authors acknowledged the technical support provided by prof. Siyamak Shahab at Belarusian State University. The authors also highly thankful to the Editor of this Journal for their valuable suggestions for strengthing this MS.

\section{Conflicts of Interest}

The authors declare no conflict of interest.

\section{References}

1. Sepay, N.; Sekar, A.; Halder, U.C.; Alarifi, A.; Afzal, M. Anti-COVID-19 terpenoid from marine sources: A docking, admet and molecular dynamics study. Journal of molecular structure 2020, 1228, 129433, https://doi.org/10.1016/j.molstruc.2020.129433.

2. Gioia, M.; Ciaccio, C.; De Simone, G.; Fasciglione, G.F.; di Masi, A.; Di Pierro, D.; Bocedi, A.; Ascenzi, P.; Coletta, M. Role of proteolytic enzymes in the COVID-19 infection and promising therapeutic approaches. Biochemical Pharmacology 2020, 182, 114225, https://doi.org/10.1016/j.bcp.2020.114225.

3. Zhu, H.; Wei, L.; Niu, P. The novel coronavirus outbreak in Wuhan, China. Global health research and policy 2020, 5, 1-3, https://doi.org/10.1186/s41256-020-00135-6.

4. Choudhary, J.; Dheeman, S.; Sharma, V.; Katiyar, P.; Karn, S.K.; Sarangi, M.K.; Chauhan, A.K.; Verma, G.; Baliyan, N. Insights of Severe Acute Respiratory Syndrome Coronavirus (SARS-CoV-2) pandemic: a current review. Biological procedures online 2021, 23, 1-22, https://doi.org/10.1186/s12575-020-00141-5.

5. da Silva, S.; Jefferson R.; Silva, C.T.A.; Guarines, K.M.; Mendes, R.P.G.; Pardee, K.; Kohl, A.; Pena, L. Clinical and laboratory diagnosis of SARS-CoV-2, the virus causing COVID-19. ACS infectious diseases 2020, 6, 2319-2336, https://doi.org/10.1021/acsinfecdis.0c00274.

6. Marinho, E.M.; de Andrade Neto, J.B.; Silva, J.; da Silva, C.R.; Cavalcanti, B.C.; Marinho, E.S.; Junior, H.V.N. Virtual screening based on molecular docking of possible inhibitors of Covid-19 main protease. Microbial Pathogenesis 2020, 148, 104365, https://doi.org/10.1016/j.micpath.2020.104365.

7. Osipiuk, J.; Azizi, S.A.; Dvorkin, S.; Endres, M.; Jedrzejczak, R.; Jones, K.A.; Kang, S.; Kathayat, R.S.; Kim, Y.; Lisnyak, V.G. Structure of papain-like protease from SARS-CoV-2 and its complexes with non-covalent inhibitors. Nat Commun 2021, 12, 1-9, https://doi.org/10.1038/s41467-021-21060-3.

8. Wang, H.; He, S.; Deng, W.; Zhang, Y.; Li, G.; Sun, J.; Zhao, W.; Yu, G.; Yin, Z.; Li, D. Comprehensive insights into the catalytic mechanism of middle east respiratory syndrome 3C-Like protease and severe acute respiratory syndrome 3C-Like protease. ACS catalysis 2020, 10, 5871-5890, https://doi.org/10.1021/acscatal.0c00110.

9. Amin, S.A.; Banerjee, S.; Ghosh, K.; Gayen, S.; Jha, T. Protease targeted COVID-19 drug discovery and its challenges: Insight into viral main protease (Mpro) and papain-like protease (PLpro) inhibitors. Bioorganic \& Medicinal Chemistry 2020, 29, 115860, https://doi.org/10.1016/j.bmc.2020.115860.

10. Jin, Z.; Zhaom, Y.; Sun, Y, Zhang, B.; Wang, H.; Wu, Y.; Zhu, Y.; Zhu, C.; Hu, T.; Du, X. Structural basis for the inhibition of SARS-CoV-2 main protease by antineoplastic drug carmofur. Nature structural \& molecular biology 2020, 27, 529-532, https://doi.org/10.1038/s41594-020-0440-6.

11. Zhang, L.; Lin, D, Sun, X.; Curth, U.; Drosten, C.; Sauerhering, L.; Becker, S.; Rox, K.; Hilgenfeld, R. Crystal structure of SARS-CoV-2 main protease provides a basis for design of improved $\alpha$-ketoamide inhibitors. Science 2020, 368, 409-412, https://doi.org/10.1126/science.abb3405.

12. Naveed, M.; Hejazi, V.; Abbas, M.; Kamboh, A.A.; Khan, G.J.; Shumzaid, M.; Ahmad, F.; Babazadeh, D.; FangFang, X.; M.G, Faezeh. Chlorogenic acid (CGA): A pharmacological review and call for further research. Biomedicine \& Pharmacotherapy 2018, 97, 67-74, https://doi.org/10.1016/j.biopha.2017.10.064.

13. Tajik, N.; Tajik, M.; Mack, I.; Enck, P. The potential effects of chlorogenic acid, the main phenolic components in coffee, on health: a comprehensive review of the literature. European Journal of Nutrition 2017, 56, 2215-2244, https://doi.org/10.1007/s00394-017-1379-1.

14. Lu, H.; Tian, Z.; Cui, Y.; Liu, Z.; Ma, X. Chlorogenic acid: A comprehensive review of the dietary sources, processing effects, bioavailability, beneficial properties, mechanisms of action, and future directions. Comprehensive Reviews in Food Science and Food Safety 2020, 19, 3130-3158, https://doi.org/10.1111/1541-4337.12620.

https://biointerfaceresearch.com/ 
15. Lukitasari, M.; Rohman, M.S.; Nugroho, D.A.; Widodo, N.; Nugrahini, N.I.P. Cardiovascular protection effect of chlorogenic acid: focus on the molecular mechanism. F1000Research 2020, 9, 1462, https://doi.org/10.12688/f1000research.26236.1.

16. Williamson, G. Protection against developing type 2 diabetes by coffee consumption: assessment of the role of chlorogenic acid and metabolites on glycaemic responses. Food \& Function 2020, 11, 4826-4833, https://doi.org/10.1039/D0FO01168A.

17. Yan, Y.; Liu, N.; Hou, N.; Dong, L.; Li, J. Chlorogenic acid inhibits hepatocellular carcinoma in vitro and in vivo. The Journal of Nutritional Biochemistry 2017, 46, 68-73, https://doi.org/10.1016/j.jnutbio.2017.04.007.

18. Ji, L.; Jiang, P.; Lu, B.; Sheng, Y.; Wang, X.; Wang, Z.; Chlorogenic acid, a dietary polyphenol, protects acetaminophen-induced liver injury and its mechanism. The Journal of Nutritional Biochemistry 2013, 24, 1911-1919, https://doi.org/10.1016/j.jnutbio.2013.05.007.

19. Nardini, M.; Cirillo, E.; Natella, F.; Scaccini, C. Absorption of phenolic acids in humans after coffee consumption. Journal of Agricultural and Food Chemistry 2002, 50, 5735-5741, https://doi.org/10.1021/jf0257547.

20. Konishi, Y.; Kobayashi, S. Transepithelial transport of chlorogenic acid, caffeic acid, and their colonic metabolites in intestinal Caco-2 cell monolayers. Journal of Agricultural and Food Chemistry 2004, 52, 25182526, https://doi.org/10.1021/jf035407c.

21. Hoelzl, C.; Knasmüller, S.; Wagner, K.H.; Elbling, L.; Huber, W.; Kager, N.; Ferk, F.; Ehrlich, V.; Nersesyan, A.; Neubauer, O. Instant coffee with high chlorogenic acid levels protects humans against oxidative damage of macromolecules. Molecular Nutrition \& Food Research 2010, 54, 1722-1733, https://doi.org/10.1002/mnfr.201000048.

22. Sapio, L.; Salzillo, A.; Illiano, M.; Ragone, A.; Spina, A.; Chiosi, E.; Pacifico, S.; Catauro, M.; Naviglio, S. Chlorogenic acid activates ERK1/2 and inhibits proliferation of osteosarcoma cells. Journal of Cellular Physiology, 2020, 235, 3741-3752, https://doi.org/10.1002/jcp.29269.

23. Evtyugin, D.D.; Magina, S.; Evtuguin, D.V. Recent advances in the production and applications of Ellagic acid and its derivatives. A review. Molecules 2020 25, 2745, https://doi.org/10.3390/molecules25122745.

24. Alfei, S.; Marengo, B.; Zuccari, G. Oxidative Stress, Antioxidant Capabilities, and Bioavailability: Ellagic Acid or Urolithins?. Antioxidants 2020, 9, 707, https://doi.org/10.3390/antiox9080707.

25. Baradaran, R.V.; Ghadiri, M.; Ramezani, M.; Askari, V.R. Antiinflammatory and anti-cancer activities of pomegranate and its constituent, ellagic acid: Evidence from cellular, animal, and clinical studies. Phytotherapy Research 2020, 34, 685-720, https://doi.org/10.1002/ptr.6565.

26. Aslan, A.; Hussein, Y.T.; Gok O.; Beyaz, S.; Erman, O.; Baspinar, S. Ellagic acid ameliorates lung damage in rats via modulating antioxidant activities, inhibitory effects on inflammatory mediators and apoptosisinducing activities. Environmental Science and Pollution Research 2020, 27, 7526-7537, https://doi.org/10.1007/s11356-019-07352-8.

27. Wang, N.; Wang, Z.Y.; Mo, S.L.; Loo, T.Y.; Wang, D.M.; Luo, H.B.; Yang, D.P.; Chen, Y.L.; Shen, J.G.; Chen, J.P. Ellagic acid, a phenolic compound, exerts antiangiogenesis effects via VEGFR-2 signaling pathway in breast cancer. Breast Cancer Research and Treatment 2012, 134, 943-955, https://doi.org/10.1007/s10549-012-1977-9.

28. Ahire, V.; Kumar, A.; Mishra, K.P.; Kulkarni, G. Ellagic Acid Enhances Apoptotic Sensitivity of Breast Cancer Cells to $\gamma$-Radiation. Nutrition Cancer 2017, 69, 904-910, https://doi.org/10.1080/01635581.2017.1339811.

29. Ceci, C.; Lacal P.M.; Tentori L.; De Martino, M.G.; Miano, R.; Graziani, G. Experimental evidence of the antitumor, Antimetastatic and antiangiogenic activity of ellagic acid. Nutrients 2018, 11, 1756, https://doi.org/10.3390/nu10111756.

30. Gupta, P.; Mohammad, T.; Khan, P.; Alajmi, M.F.; Hussain, A.; Rehman, M.T.; Hassan M.I. Evaluation of ellagic acid as an inhibitor of sphingosine kinase 1: A targeted approach towards anti-cancer therapy. Biomedicine \& Pharmacotherapy 2019, 118, 109245, https://doi.org/10.1016/j.biopha.2019.109245.

31. Yousuf, M.; Shamsi, A.; Khan, P.; Shahbaaz, M.; AlAjmi, M.F.; Hussain, A.; Hassan, G.M.; Islam, A.; Rizwanul, H.; Q.M, Hassan.; M. Ellagic acid controls cell proliferation and induces apoptosis in breast cancer cells via inhibition of cyclin-dependent kinase 6. International Journal of Molecular Sciences 2020, 21, 3526, https://doi.org/10.3390/ijms21103526.

32. Wang, N.; Wang, Q.; Tang, H.; Zhang, F.; Zheng, Y.; Wang, S.; Zhang, J.; Wang, Z.; Xie X. Direct inhibition of ACTN4 by ellagic acid limits breast cancer metastasis via regulation of $\beta$-catenin stabilization in cancer stem cells. J Exp Clin Cancer Res 2017, 36, 1-19, https://doi.org/10.1186/s13046-017-0635-9. 
33. Chang, S.; Li, B.; Chen, T.; He, X.; Wu, B. Determination of Quisqualic Acid in quisqualis fructus by Precolumn Derivatization and High Performance Liquid Chromatography. Journal of Analytical Chemistry 2020, 75, 1018-1023, https://doi.org/10.1134/S1061934820080055.

34. Murakoshi I.; Kaneko M.; Koide C.; Ikegami F. Enzymatic synthesis of the neuroexcitatory amino acid quisqualic acid by cysteine synthase, Phytochemistry 1986, 25, 2759-2763, https://doi.org/10.1016/S00319422(00)83736-X.

35. Chase, L.A.; Roon R.J.; Wellman, L.; Beitz, A.J, Koerner, J.F. L-Quisqualic acid transport into hippocampal neurons by a cystine-sensitive carrier is required for the induction of quisqualate sensitization. Neuroscience 2001, 106, 287-301, https://doi.org/10.1016/S0306-4522(01)00278-0.

36. Bitzer, M.; Schaeffel, F. Effects of quisqualic acid on retinal ZENK expression induced by imposed defocus in the chick eye. Optometry and Vision Science 2004, 81, 127-136, https://doi.org/10.1097/00006324200402000-00011.

37. Rochford, J.; Sen, A.P.; Rousse, I. Welner S.A. The effect of quisqualic acid-induced lesions of the nucleus basalis magnocellularis on latent inhibition. Brain Research Bulletin 1996, 41, 313-317, https://doi.org/10.1016/S0361-9230(96)00191-8.

38. Rasool, N.; Akhtar, A.; Hussain, W. Insights into the inhibitory potential of selective phytochemicals against Mpro of 2019-nCoV: a computer-aided study. Structural Chemistry 2020, 31, 1777-1783, https://doi.org/10.1007/s11224-020-01536-6.

39. Shahab, S.; Sheikhi, M.; Alnajjar, R.; Al Saud, S.; Khancheuski, M.; Strogova, A. DFT investigation of atazanavir as potential inhibitor for 2019-nCoV coronavirus M protease. Journal of Molecular Structure 2020, 1228, 129461, https://doi.org/10.1016/j.molstruc.2020.129461.

40. Agamah, F.E.; Mazandu, G.K.; Hassan, R.; Bope, C.D.; Thomford N.E, Ghansah, A.; Chimusa E.R.. Computational/In silico methods in drug target and lead prediction. Briefings in Bioinformatics 2020, 21, 1663-1675, https://doi.org/10.1093/bib/bbz103

41. D. Rognan, The impact of In silico screening in the discovery of novel and safer drug candidates, Pharmacology \& Therapeutics 2017, 175, 47-66, https://doi.org/10.1016/j.pharmthera.2017.02.034.

42. Sachdev, K.; Gupta, M.K. A. Comprehensive review of feature based methods for drug target interaction prediction. Journal of biomedical informatics 2019, 93, 103159, https://doi.org/10.1016/j.jbi.2019.103159.

43. Lipinski, C.A.; Lombardo, F.; Dominy B.W.; Feeney, P.J. Experimental and computational approaches to estimate solubility and permeability in drug discovery and development settings. Advanced Drug Delivery Reviews 1997, 23, 3-25, https://doi.org/10.1016/S0169-409X(96)00423-1.

44. Husain, A.; Ahmad, A.; Khan, S.A.; Asif, M.; Bhutani, R.; Al-Abbasi, F.A. Synthesis, molecular properties, toxicity and biological evaluation of some new substituted imidazolidine derivatives in search of potent antiinflammatory agents. Saudi Pharmaceutical Journal 2016, 24, 104-114, https://doi.org/10.1016/j.jsps.2015.02.008.

45. Frisch, M.J.; Trucks, G.W.; Schlegel, H.B.; Scuseria, G.E.; Robb, M.A.; Cheeseman, J.R.; Montgomery, J.A., Jr.; Vreven, T.; Kudin, K.N.; Burant, J.C.; et al. Gaussian 09 Revision, E01; Wallingford, CT, USA, 2009.

46. Yanai, T.; Tew, D.P.; Handy, N.C. A new hybrid exchange-correlation functional using the Coulombattenuating method (CAM-B3LYP). Chemical Physics Letters 2004, 393, 51-57, https://doi.org/10.1016/j.cplett.2004.06.011.

47. Lynch, B.J.; Truhlar D.G. Small basis sets for calculations of barrier heights, energies of reaction, electron affinities, geometries, and dipole moments. Theoretical Chemistry Accounts 2004, 111, 335-344, https://doi.org/10.1007/s00214-003-0518-3

48. Shahab, S.; Sheikhi, M. Antioxidant Properties of the Phorbol: A DFT Approach. Russian Journal of Physical Chemistry B 2020, 14, 15-18, https://doi.org/10.1134/S1990793120010145.

49. Frisch, A.; Nielson, A.B.; Holder, A.J. GAUSSVIEW User Manual, Gaussian Inc., Pittsburgh, PA, 2000.

50. Trott, O.; Olson, A.J. AutoDock Vina: improving the speed and accuracy of docking with a new scoring function, efficient optimization, and multithreading. Journal of Computational Chemistry 2009, 31, 455-461, https://doi.org/10.1002/jcc.21334.

51. Sudomova, M.; Hassan, S.T.S.; Khan, H.; Rasekhian, M.; Nabavi, SM. A multi-biochemical and In silico study on anti-enzymatic actions of pyroglutamic acid against pde-5, ace, and urease using various analytical techniques: unexplored pharmacological properties and cytotoxicity evaluation. Biomolecules 2019, 9, 9392, https://doi.org/10.3390/biom9090392. 
52. Ali, M.C.; Nur, A.J.; Khatun, M.S.; Dash, R.; Rahman, M.M.; Karim, M.M. Identification of potential SARSCoV-2 main protease inhibitors from Ficus Carica Latex: An in-silico approach. J Adv Biotechnol Exp Ther 2020, 3, 57-67, https://doi.org/10.5455/jabet.2020.d157.

53. Amati, M.; Stoia, S.; Baerends, E.J. The Electron Affinity as the Highest Occupied Anion Orbital Energy with a Sufficiently Accurate Approximation of the Exact Kohn-Sham Potential. Journal of Chemical Theory and Computation 2019, 16, 443-452, https://doi.org/10.1021/acs.jctc.9b00981.

54. Sheikhi, M.; Shahab, S.; Khaleghian, M.; Hajikolaee, F.H.; Balakhanava, I.; Alnajjar, R. Adsorption properties of the molecule resveratrol on CNT (8, 0-10) nanotube: geometry optimization, molecular structure, spectroscopic (NMR, UV/Vis, excited state), FMO, MEP and HOMO-LUMO investigations. Journal of Molecular Structure 2018, 1160, 479-487, https://doi.org/10.1016/j.molstruc.2018.01.005.

55. Shahab, S.; Sheikhi M.; Filippovich L.; Anatol'evich, D.E.; Yahyaei H. Quantum chemical modeling of new derivatives of (E, E)-azomethines: synthesis, spectroscopic (FT-IR, UV/Vis, polarization) and thermophysical investigations. Journal of Molecular Structure 2017, 1137, 335-348, https://doi.org/10.1016/j.molstruc.2017.02.056.

56. Shahab, S.; Sheikhi, M.; Filippovich, L.; Alnajjar, R.; Ihnatovich, Z.; Laznev, K.; Strogova, A.; Atroshko, M.; Drachilovskaya, M. Quantum-chemical modeling, spectroscopic (FT-IR, excited states, UV/Vis, polarization, and Dichroism) studies of two new benzo [d] oxazole derivatives. Journal of Molecular Structure 2020, 1202, 127352, https://doi.org/10.1016/j.molstruc.2019.127352. 